\title{
Renata Knap*
}

Uniwersytet Szczeciński

\section{KRAJE NAJS $\longleftarrow A B I E J ~ R O Z W I N I E T T E$ W ŚWIATOWEJ GOSPODARCE RYBNEJ}

\begin{abstract}
Streszczenie
Celem artykułu jest określenie tendencji rozwoju gospodarki rybnej krajów najsłabiej rozwiniętych (LDC) oraz ich roli w światowej gospodarce rybnej w latach 1970-2015. Z przeprowadzonych badań wynika, że tendencje rozwoju sektora rybnego LDC kształtowały się korzystnie, o czym świadczy wysoka dynamika produkcji, konsumpcji i handlu artykułami rybnymi, rosnące dodatnie saldo obrotów produktami rybnymi oraz międzynarodowa przewaga konkurencyjna sektora rybnego. Pomimo wzrostu udziału w globalnej gospodarce rybnej, rola LDC w tej dziedzinie gospodarki światowej była relatywnie mała. Do głównych przeszkód rozwoju sektora rybnego w wielu LDC należały: niekorzystne warunki naturalne, niski poziom rozwoju gospodarczego oraz niedostatek zasobów pracy i kapitału.
\end{abstract}

Słowa kluczowe: kraje najsłabiej rozwinięte, rozwój sektora rybnego, światowa gospodarka rybna

\footnotetext{
*Adres e-mail: renataknap@onet.pl.
} 


\section{Wprowadzenie}

Jednym z najbardziej charakterystycznych zjawisk w światowej gospodarce rybnej w ostatnim czterdziestoleciu był dynamiczny rozwój gospodarek rybnych krajów rozwijających się. W bardzo zróżnicowanej grupie państw rozwijających się szczególnie ważną rolę przypisuje się rozwojowi sektora rybnego w krajach najsłabiej rozwiniętych, jako tej dziedzinie gospodarki, która może znacząco przyczynić się do utrzymania i podwyższania stopy wzrostu gospodarczego oraz redukcji ubóstwa, głodu i niedożywienia (OECD/FAO, 2015; Knap, 2012; Thorpe 2005).

Celem artykułu jest określenie tendencji rozwoju sektora rybnego krajów najsłabiej rozwiniętych oraz ich roli w światowej gospodarce rybnej w latach 19702015.

W pierwszej części opracowania przedstawiono wyniki analizy rozwoju produkcji rybołówstwa krajów najsłabiej rozwiniętych (Least Developed Countries $\mathrm{LDC}^{1}$ ), w drugiej zaprezentowano kształtowanie się konsumpcji ryb i produktów rybnych badanej grupy krajów, w trzeciej natomiast omówiono tendencje w obrotach z zagranicą artykułami rybnymi LDC.

Do określenia tendencji rozwoju produkcji, konsumpcji i handlu artykułami rybnymi zastosowano metody analizy statystycznej w postaci narzędzi analizy struktury zbiorowości i dynamiki zjawisk. W ocenie konkurencyjności handlowej LDC wykorzystano wskaźnik ujawnionej przewagi komparatywnej $\mathrm{RCA}_{i}$ (reveald comparative advantage). Materiał statystyczny wykorzystany w badaniach pobrano z bazy danych FAO oraz UNCTAD.

Badaniami objęto lata 1970-2015, czyli okres od zmiany zasad użytkowania morza (powszechnego wprowadzania wyłącznych stref ekonomicznych) do roku, za który dostępne były dane statystyczne. Ze względu na ograniczenia w bazie danych FAO, analizy konsumpcji obejmują lata 1970-2013, a handlu - okres 1976-2013.

\section{Produkcja rybołówstwa}

Całkowita produkcja rybołówstwa LDC wzrosła w okresie 1970-2015 z 2,8 mln do $12,5 \mathrm{mln}$ ton, czyli prawie 4,5-krotnie. W pierwszej dekadzie badanego okresu (2017a).

Do krajów najsłabiej rozwiniętych ONZ zalicza obecnie 48 krajów. Szerzej zob. UNCTAD 
wykazywała stagnację, a nawet spadek, ale od połowy lat 90 . XX wieku nastąpiło wyraźne przyspieszenie tempa wzrostu połowów i akwakultury LDC (rys. 1).

Rysunek 1. Wielkość produkcji rybołówstwa LDC w latach 1970-2015 (mln t)

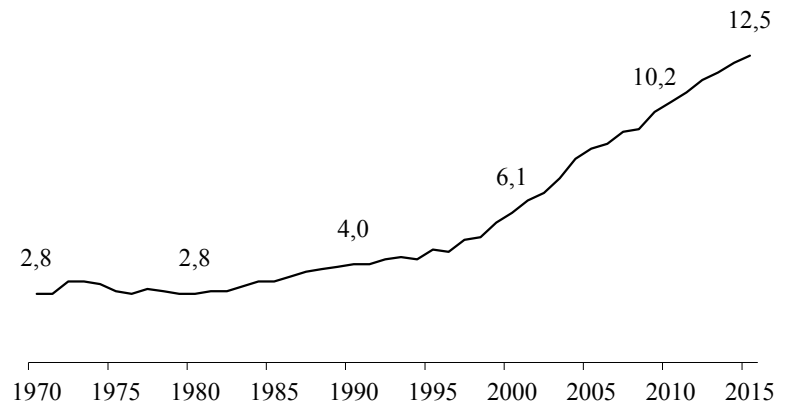

Źródło: opracowanie własne na podstawie FAO (2017b).

W XXI wieku dynamika produkcji LDC przewyższała dynamikę produkcji światowego rybołówstwa, w efekcie czego udział krajów najsłabiej rozwiniętych w globalnych połowach i akwakulturze zwiększył się z 4,1\% w 1970 roku do 6,2\% w 2015 roku (tab. 1).

Tabela 1. Udział w produkcji światowego rybołówstwa oraz dynamika produkcji LDC wybranych grup krajów i świata w latach 1970-2015 (\%)

\begin{tabular}{|l|r|r|r|r|r|r|c|}
\hline \multicolumn{1}{|c|}{ Wyszczególnienie } & 1970 & 1980 & 1990 & 2000 & 2010 & 2015 & $\begin{array}{c}\text { Produkcja } \\
2015 \\
(1970=100)\end{array}$ \\
\hline LDC & 4,1 & 3,8 & 3,9 & 4,5 & 6,4 & 6,2 & 447,1 \\
\hline Pozostałe rozwijające się & 44,2 & 43,0 & 54,9 & 71,2 & 75,9 & 78,8 & 531,4 \\
\hline Kraje rozwinięte & 51,7 & 53,2 & 41,2 & 24,3 & 17,7 & 15,0 & 86,2 \\
\hline Świat & 100,0 & 100,0 & 100,0 & 100,0 & 100,0 & 100,0 & 296,3 \\
\hline
\end{tabular}

Źródło: opracowanie własne na podstawie FAO (2017b).

W całym badanym okresie w strukturze produkcji LDC według sposobu pozyskania ryb i innych organizmów wodnych dominującą rolę odgrywały połowy, jednak ich udział zmniejszył się z 97,6\% w 1970 roku do 69,9\% w 2015 roku. Zgodnie $\mathrm{z}$ tendencją występującą $\mathrm{w}$ światowym rybołówstwie, w produkcji LDC wzrosło 
znaczenie hodowli, z zaledwie 2,4\% w 1970 roku do aż 30,1\% w 2015 roku (tab. 2). Odsetek ten był jednak niższy niż w globalnym rybołówstwie, w którym w 2015 roku z akwakultury pochodziło aż 53,1\% całkowitej produkcji (obliczenia własne na podstawie FAO, 2017b).

Większość produkcji rybołówstwa LDC pochodziła z wód śródlądowych, na którą w 2015 roku przypadało 61,2\% produkcji całkowitej. Udział produkcji morskiej zmniejszył się z 41,7\% w 1970 roku do 38,8\% w 2015 roku (tab. 2). Wysoki odsetek produkcji śródlądowej można uznać za specyfikę rybołówstwa LDC, ponieważ w krajach rozwiniętych gospodarczo, pozostałych krajach rozwijających się oraz w ujęciu globalnym dominującą rolę odgrywała w badanym okresie produkcja morska (w 2015 r. jej udział wynosił odpowiednio 95,2; 67,4 i 69,8\%) (obliczenia własne na podstawie FAO, 2017b).

Tabela 2. Struktura produkcji rybołówstwa krajów najsłabiej rozwiniętych w latach 1970-2015 (\%)

\begin{tabular}{|c|c|c|c|c|c|c|}
\hline \multirow{2}{*}{ Lata } & \multicolumn{3}{|c|}{ Sposób pozyskania } & \multicolumn{3}{c|}{ Źródła pochodzenia } \\
\cline { 2 - 7 } & połowy & akwakultura & $\begin{array}{c}\text { produkcja } \\
\text { ogółem }\end{array}$ & morska & śódlądowa & $\begin{array}{c}\text { produkcja } \\
\text { ogółem }\end{array}$ \\
\hline 1970 & 97,6 & 2,4 & 100,0 & 41,7 & 58,3 & 100,0 \\
\hline 1980 & 96,6 & 3,4 & 100,0 & 42,2 & 57,8 & 100,0 \\
\hline 1990 & 93,9 & 6,1 & 100,0 & 48,4 & 51,6 & 100,0 \\
\hline 2000 & 85,2 & 14,8 & 100,0 & 46,9 & 53,1 & 100,0 \\
\hline 2010 & 75,5 & 24,5 & 100,0 & 40,7 & 59,3 & 100,0 \\
\hline 2015 & 69,9 & 30,1 & 100,0 & 38,8 & 61,2 & 100,0 \\
\hline
\end{tabular}

Źródło: opracowanie własne na podstawie FAO (2017b).

Przechodząc do analizy struktury produkcji LDC według krajów, należy podkreślić bardzo duże zróżnicowane tej grupy państw ze względu na naturalne uwarunkowania rozwoju rybołówstwa. Do LDC należały zarówno kraje śródlądowe, jak i kraje posiadające wyłączną jurysdykcję nad ogromnymi obszarami morskimi, w tym małe kraje wyspiarskie. Ponadto kraje LDC różniły się wielkością i jakością zasobów rybnych w swych wyłącznych strefach ekonomicznych (WSE) na morzu, wyposażeniem w zbiorniki wodne na lądzie i ich zasobnością, jak i warunkami do prowadzenia akwakultury (FAO, 2017a). 
W całym badanym okresie dominującą rolę w rybołówstwie LDC odgrywała najliczniejsza grupa krajów z dostępem do morza (z wyłączeniem małych wyspiarskich), na którą przypadało 85,6\% i więcej produkcji. Drugą grupą, o malejącym udziale w produkcji całkowitej, były kraje śródlądowe (spadek udziału z 12,5\% w 1970 r. do 7,4\% w 2015 r.). Najmniejszy udział w produkcji, wykazujący jednak tendencję wzrostową, przypadał na małe kraje wyspiarskie (wzrost z 1,0 do 3,0\%) - (tab. 3).

Tabela 3. Struktura produkcji rybołówstwa LDC według grup krajów* (\%)

\begin{tabular}{|c|c|c|c|c|}
\hline Lata & $\begin{array}{c}\text { Śródlądowe } \\
(17)\end{array}$ & $\begin{array}{c}\text { Małe wyspiarskie } \\
(9)\end{array}$ & $\begin{array}{c}\text { Pozostałe } \\
(22)\end{array}$ & $\begin{array}{c}\text { Razem LDC } \\
(48)\end{array}$ \\
\hline 1970 & 12,5 & 1,0 & 86,6 & 100 \\
\hline 1980 & 12,0 & 2,4 & 85,6 & 100 \\
\hline 1990 & 9,3 & 3,5 & 87,2 & 100 \\
\hline 2000 & 8,2 & 2,8 & 89,1 & 100 \\
\hline 2010 & 6,4 & 2,8 & 90,8 & 100 \\
\hline 2015 & 7,4 & 3,0 & 89,6 & 100 \\
\hline
\end{tabular}

* Liczbę krajów LDC w danej grupie podano w nawiasach.

Źródło: opracowanie własne na podstawie FAO (2017b).

Małe wyspiarskie LDC, które uzyskały wyłączne prawo do eksploatacji zasobów ryb w bardzo rozległych obszarach własnych WSE, nie posiadały często możliwości odpowiedniego rozwoju rybołówstwa ze względu na niski poziom rozwoju gospodarek i niedostatek innych zasobów (pracy i kapitału). Czerpały jednak bardzo duże korzyści w postaci dochodów z opłat za prawo do połowów w swoich WSE udzielane flotom rybackim obcych państw. Dla przykładu, w 2014 roku dochody Kiribati ze sprzedaży licencji rybackich wyniosły $127,3 \mathrm{mln}$ USD i stanowiły aż 68,4\% PKB (IMF, 2015, s. 26; MFED, 2015, s. 4).

Do najważniejszych zmian w strukturze produkcji rybołówstwa LDC według regionów geograficznych należał wzrost roli krajów azjatyckich i utrata pierwszej pozycji przez najliczniejszą grupę państw afrykańskich (rys. 2). Zjawisko to można w znacznym stopniu tłumaczyć odmiennymi tendencjami rozwoju gospodarczego, rzutującymi na rozwój sektora rybnego w latach 80. i 90. XX wieku, a mianowicie dynamicznym wzrostem w krajach Azji i regresem gospodarczym w krajach Afryki. 
Rysunek 2. Struktura produkcji rybołówstwa LDC według kontynentów (\%)

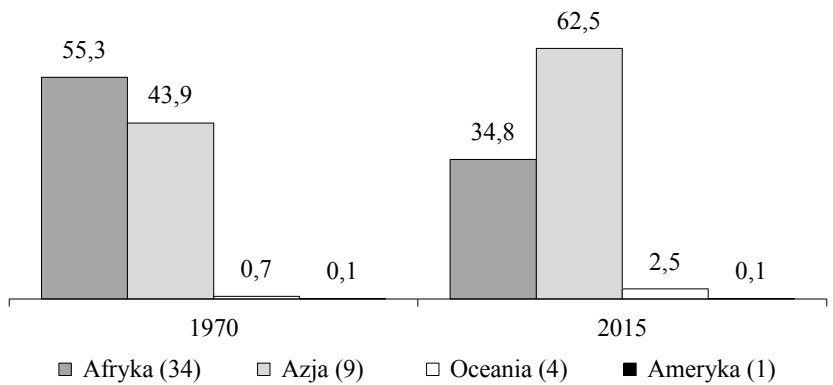

Uwaga: W nawiasach podano liczbę LDC.

Źródło: opracowanie własne na podstawie FAO (2016).

Tabela 4. Struktura produkcji rybołówstwa LDC według krajów w latach 1970 i 2015 (\%)

\begin{tabular}{|c|c|c|c|}
\hline \multicolumn{2}{|c|}{1970} & \multicolumn{2}{|c|}{2015} \\
\hline 1. Bangladesz ${ }^{1}$ & 24,7 & 1. Bangladesz ${ }^{1}$ & 29,5 \\
\hline 2. Myanmar & 15,5 & 2. Myanmar ${ }^{1}$ & 23,7 \\
\hline 3. Angola ${ }^{2}$ & 13,4 & 3. Kambodża ${ }^{1}$ & 6,0 \\
\hline 4. Tanzania $^{2}$ & 6,9 & 4. Tanzania $^{2}$ & 4,7 \\
\hline 5. Kongo, Dem. Rep. ${ }^{2}$ & 4,9 & 5. Uganda ${ }^{2 a}$ & 4,1 \\
\hline 6. Uganda ${ }^{2 \mathrm{a}}$ & 4,6 & 6. Angola ${ }^{2}$ & 4,0 \\
\hline 7. Senegal ${ }^{2}$ & 4,3 & 7. Senegal ${ }^{2}$ & 3,4 \\
\hline 8. Mali2a & 3,9 & 8. Mauretania ${ }^{2}$ & 3,2 \\
\hline 9. $\mathrm{Czad}^{2 \mathrm{aa}}$ & 2,5 & 9. Mozambik ${ }^{2}$ & 2,3 \\
\hline 10. Kambodża ${ }^{1}$ & 1,9 & 10. Kongo, Dem. Rep. ${ }^{2}$ & 1,9 \\
\hline 11. Madagaskar ${ }^{2}$ & 1,9 & 11. Sierra Leone ${ }^{2}$ & 1,6 \\
\hline 12. Zambia $^{2}$ & 1,9 & 12. Laos $^{1 \mathrm{a}}$ & 1,4 \\
\hline 13. Mauretania ${ }^{2}$ & 1,8 & 13. Jemen ${ }^{1}$ & 1,3 \\
\hline 14. Malawi ${ }^{2 a}$ & 1,7 & 14. Kiribati $^{3 \mathrm{~b}}$ & 1,2 \\
\hline 15. Benin ${ }^{2}$ & 1,5 & 15. Malawi ${ }^{2 \mathrm{a}}$ & 1,2 \\
\hline Razem 1-15 & 91,4 & Razem 1-15 & 89,5 \\
\hline Pozostałe & 8,6 & Pozostałe & 10,5 \\
\hline Razem LDC & 100,0 & Razem LDC & 100,0 \\
\hline
\end{tabular}

${ }^{1}$ Azja; ${ }^{2}$ Afryka; ${ }^{3}$ Oceania; ${ }^{a}$ śródlądowe; ${ }^{b}$ małe wyspiarskie.

Źródło: opracowanie własne na podstawie FAO (2017b). 
Strukturę produkcji według poszczególnych krajów charakteryzował w całym badanym okresie wysoki stopień koncentracji. W 1970 roku na trzech największych producentów przypadało 53,6\% całkowitej produkcji rybołówstwa LDC, a w 2015 roku odsetek ten wynosił aż 59,2\% (tab. 4). Z porównania grup 15 największych producentów w latach 1970 i 2015 wynika, że na liście tej wzrosła liczba krajów Azji kosztem przedstawicieli Afryki, zmniejszyła się liczba krajów śródlądowych, pojawił się natomiast przedstawiciel małych krajów wyspiarskich. Zmiany te odzwierciedlały ukazane wcześniej przekształcenia w strukturze produkcji LDC według grup krajów (tab. 4 i 3, rys. 2).

\section{Konsumpcja ryb i produktów rybnych}

Rosnąca produkcja rybołówstwa przyczyniała się do wzrostu podaży żywności pochodzenia wodnego w krajach najsłabiej rozwiniętych. Całkowita roczna konsumpcja (tzw. apparent consumption) artykułów rybnych LDC zwiększyła się w latach 1970-2013 z 2,4 mln do 11,2 mln t. Tempo wzrostu konsumpcji całkowitej krajów najsłabiej rozwiniętych było wyższe niż średnia światowa, wzrósł więc udział LDC w globalnej konsumpcji ryb i produktów rybnych z 6 do 7,9\% (tab. 5).

Tabela 5. Struktura i dynamika całkowitej konsumpcji żywności pochodzenia wodnego według grup krajów w latach 1970-2013 (\%)

\begin{tabular}{|l|r|r|r|r|r|r|c|}
\hline \multicolumn{1}{|c|}{ Wyszczególnienie } & 1970 & 1980 & 1990 & 2000 & 2010 & 2013 & $\begin{array}{c}\text { Podaż 2013 } \\
(1970=100)\end{array}$ \\
\hline LDC & 6,0 & 5,3 & 5,3 & 5,3 & 7,6 & 7,9 & 466,9 \\
\hline Pozostałe kraje rozwijające się & 35,1 & 41,8 & 49,4 & 63,3 & 67,8 & 69,7 & 700,9 \\
\hline Kraje rozwinięte & 59,0 & 52,9 & 45,4 & 31,4 & 24,6 & 22,4 & 133,6 \\
\hline Świat & 100,0 & 100,0 & 100,0 & 100, & 100,0 & 100,0 & 352,2 \\
\hline
\end{tabular}

Źródło: opracowanie własne na podstawie FAO (2016a).

Wysoka dynamika konsumpcji całkowitej, przewyższająca tempo wzrostu populacji, skutkowała wzrostem średniego rocznego spożycia per capita ryb i produktów rybnych LDC z 7,8 kg w 1970 roku do 12,5 kg w 2013 roku. Wartość tego wskaźnika była jednak niższa w całym analizowanym okresie niż średnia światowa 
i znacznie niższa niż w krajach rozwiniętych gospodarczo, a od połowy lat 80 . XX wieku - mniejsza niż w pozostałych krajach rozwijających się (tab. 6).

Tabela 6. Średnioroczne spożycie per capita żywności pochodzenia wodnego LDC na tle średniej światowej i wybranych grup krajów w latach 1970-2013 (kg)

\begin{tabular}{|l|r|r|r|r|r|r|}
\hline \multicolumn{1}{|c|}{ Wyszczególnienie } & 1970 & 1980 & 1990 & 2000 & 2010 & 2013 \\
\hline LDC & 7,8 & 7,4 & 7,5 & 7,9 & 11,7 & 12,5 \\
\hline Pozostałe kraje rozwijające się & 6,1 & 6,9 & 10,0 & 14,8 & 18,7 & 20,2 \\
\hline Kraje rozwinięte & 22,0 & 23,1 & 25,9 & 23,2 & 23,2 & 22,7 \\
\hline Świat & 10,9 & 11,5 & 13,5 & 15,9 & 18,7 & 19,7 \\
\hline
\end{tabular}

Źródło: opracowanie własne na podstawie FAO (2016a).

Wielkość spożycia artykułów rybnych w poszczególnych krajach najsłabiej rozwiniętych była bardzo zróżnicowana, a skala dysproporcji, mierzona różnicą między najwyższym a najniższym spożyciem na osobę, uległa zwiększeniu (z około $59 \mathrm{~kg} \mathrm{w} 1970$ r. do około $72 \mathrm{~kg} \mathrm{w} 2013$ r.). Do LDC należały kraje zaliczane

Tabela 7. LDC o najwyższym i najniższym spożyciu per capita ryb i produktów rybnych w 2013 roku $(\mathrm{kg})$

\begin{tabular}{|c|c|c|c|}
\hline \multicolumn{2}{|c|}{ Najwyższe spożycie } & \multicolumn{2}{|c|}{ Najniższe spożycie } \\
\hline Kiribati $^{3 b}$ & 72,9 & Afganistan $^{\text {la }}$ & 0,1 \\
\hline Myanmar $^{1}$ & 60,7 & Etiopia $^{2 \mathrm{a}}$ & 0,2 \\
\hline Tuvalu $^{3 b}$ & 43,3 & Erytrea $^{2}$ & 0,4 \\
\hline Kambodża $^{1}$ & 41,4 & Lesotho ${ }^{2 a}$ & 0,8 \\
\hline Wyspy Salomona $^{3 b}$ & 33,6 & Sudan $^{2}$ & 0,9 \\
\hline Sierra Leone $^{2}$ & 32,3 & Gwinea-Bissau $^{2}$ & 1,4 \\
\hline Vanuatu $^{3 b}$ & 31,0 & Burundi $^{2}$ & 2,0 \\
\hline Wyspy Św. Tomasza i Książęca ${ }^{2 b}$ & 25,4 & Nepal $^{\text {la }}$ & 2,2 \\
\hline Gwinea Równikowa² & 24,5 & Jemen $^{1}$ & 2,5 \\
\hline Gambia $^{2}$ & 24,1 & Niger $^{2 \mathrm{a}}$ & 3,1 \\
\hline Senegal $^{2}$ & 23,9 & Somalia $^{2}$ & 3,1 \\
\hline Bangladesz $^{1}$ & 21,2 & Sudan Południowy ${ }^{2 a}$ & 3,3 \\
\hline $\operatorname{Laos}^{1 \mathrm{a}}$ & 19,8 & Dżibuti $^{2}$ & 3,8 \\
\hline Angola $^{2}$ & 18,6 & Rwanda $^{2 a}$ & 3,9 \\
\hline Komory ${ }^{2 b}$ & 16,4 & Liberia $^{2}$ & 4,2 \\
\hline
\end{tabular}

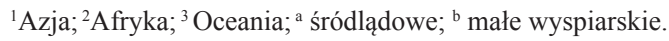

Źródło: opracowanie własne na podstawie FAO (2016a). 
do największych światowych konsumentów per capita, jak i kraje o najniższym spożyciu ryb i produktów rybnych w skali świata. Wysoki poziom spożycia per capita charakteryzował największych producentów ryb i produktów rybnych LDC (Bangladesz, Myanmar, Kambodża, Angola, Senegal, Laos) oraz małe wyspiarskie LDC o relatywnie małej wielkości produkcji, która zapewniała jednak wysoką podaż artykułów rybnych niewielkiej liczbie ludności tych krajów. W grupie LDC o najniższym poziomie spożycia na osobę znajdowały się kraje śródlądowe oraz pozostałe, o relatywnie małej produkcji rybołówstwa i/lub dużej liczbie ludności (tab. 7).

Związany z rozwojem krajowego rybołówstwa wzrost podaży żywności pochodzenia wodnego miał szczególne znaczenie dla analizowanej grupy krajów, bowiem aż 38 z 48 LDC należało w 2013 roku do krajów o niskim dochodzie i deficycie żywnościowym (Low-Income Food-Deficit Countries - LIFDC), a w wielu z nich ryby i produkty rybne były podstawowym źródłem białka zwierzęcego (FAO, 2016c, s. 71).

\section{Obroty z zagranicą rybami i produktami rybnymi}

W latach 1976-2013 znacznie wzrosły obroty z zagranicą LDC produktami rybnymi. Wartość eksportu zwiększyła się ze $140 \mathrm{mln}$ do 2,8 mld USD, czyli prawie 20-krotnie, a import w ujęciu wartościowym wzrósł z 73,3 mln USD do ponad $1 \mathrm{mld}$ USD, czyli blisko 14-krotnie (tab. 8).

Tabela 8. Wartość i wolumen obrotów produktami rybnymi LDC w latach 1976-2013

\begin{tabular}{|c|c|c|c|c|}
\hline \multirow{2}{*}{ Lata } & \multicolumn{2}{|c|}{$\begin{array}{c}\text { Wartość } \\
\text { (mln USD) }\end{array}$} & \multicolumn{2}{c|}{$\begin{array}{c}\text { Wolumen } \\
\text { (tys. t) }\end{array}$} \\
\cline { 2 - 5 } & eksport & import & eksport & import \\
\hline 1976 & 140,0 & 73,3 & 117,2 & 128,3 \\
\hline 1980 & 268,8 & 125,7 & 152,1 & 164,3 \\
\hline 1990 & 758,5 & 217,3 & 294,2 & 281,1 \\
\hline 2000 & 1327,1 & 131,1 & 598,1 & 200,0 \\
\hline 2010 & 2360,4 & 581,4 & 1087,5 & 533,0 \\
\hline 2013 & 2780,2 & 1019,4 & 1482,3 & 718,9 \\
\hline
\end{tabular}

Źródło: opracowanie własne na podstawie FAO (2016b). 
Udział LDC w wartości globalnego eksportu ryb i produktów rybnych charakteryzowała ogółem tendencja wzrostowa, tylko w ostatniej dekadzie wystąpił trend spadkowy. W efekcie, w 2013 roku, na LDC przypadało 2\% wartości światowego eksportu artykułów rybnych, a więc tylko o 0,2 p.p. więcej niż w 1976 roku. Odsetek krajów najsłabiej rozwiniętych w światowym imporcie wykazywał natomiast odwrotny, spadkowy trend, który w ostatniej dekadzie uległ odwróceniu i ostatecznie udział LDC w wartości globalnego importu na koniec badanego okresu był taki, jak na jego początku, i wynosił $0,8 \%$ (tab. 9).

Tabela 9. Udział LDC w globalnych obrotach artykułami rybnymi w latach 1976 i 2013 (\%)

\begin{tabular}{|l|r|r|r|r|}
\hline \multirow{2}{*}{ Wyszczególnienie } & \multicolumn{2}{c|}{ Eksport } & \multicolumn{2}{c|}{ Import } \\
\cline { 2 - 5 } & 1976 & 2013 & 1976 & 2013 \\
\hline LDC & 1,8 & 2,00 & 0,8 & 0,8 \\
\hline Pozostałe kraje rozwijające się & 32,0 & 48,8 & 12,6 & 26,7 \\
\hline Kraje rozwinięte & 63,1 & 46,0 & 86,6 & 72,5 \\
\hline Świat & 100,0 & 100,0 & 100,0 & 100,0 \\
\hline
\end{tabular}

Źródło: opracowanie własne na podstawie FAO (2016b).

Rysunek 3. Średnie ceny (unit value) w eksporcie i imporcie artykułów rybnych LDC w latach 1976-2013 (USD/t)

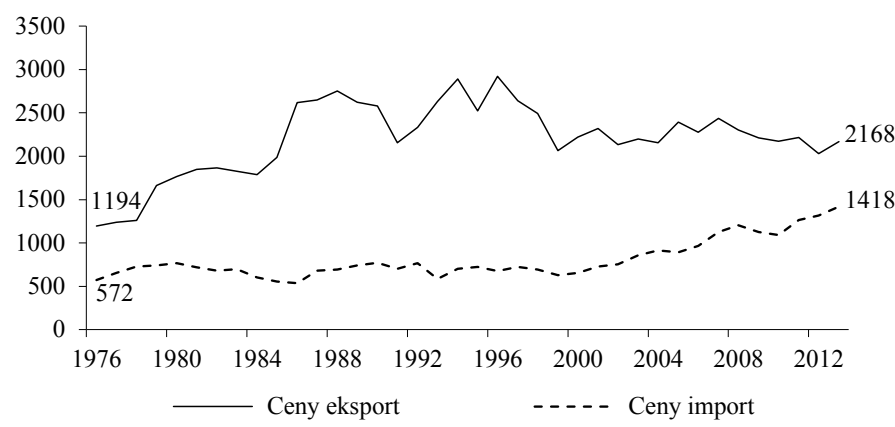

Źródło: opracowanie własne na podstawie FAO (2016b).

Z porównania średnich cen (unit value) w wywozie i przywozie LDC wynika, że w całym badanym okresie ceny uzyskiwane w eksporcie znacznie przewyższały ceny płacone za importowane artykuły rybne (rys. 3). Świadczy to o zróżnicowaniu 
rodzajowym handlu rybnego LDC, polegającym na dominacji w eksporcie bardziej wartościowych, droższych gatunków ryb i produktów rybnych, w imporcie zaś mniej wartościowych, tańszych artykułów rybnych.

Korzystne relacje cen w obrotach artykułami rybnymi LDC były ważnym czynnikiem rosnącego, dodatniego salda w handlu artykułami rybnymi w całym badanym okresie, nawet w tych latach, w których bilans ilościowy był ujemny (rys. 4).

Rysunek 4. Bilans handlu zagranicznego artykułami rybnymi LDCs w ujęciu wartościowym i ilościowym w latach 1976-2013
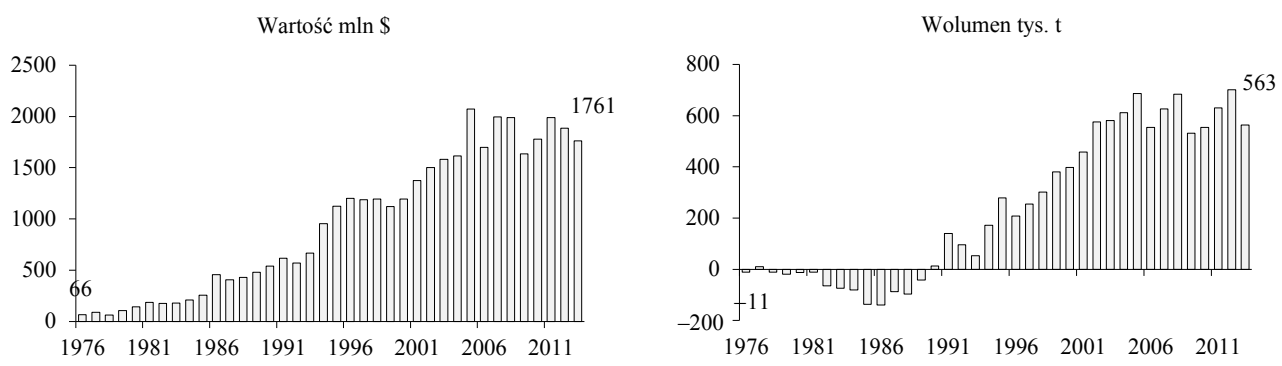

Źródło: opracowanie własne na podstawie FAO (2016b).

Z analizy najważniejszych zmian w strukturze obrotów produktami rybnymi LDC w układzie poszczególnych krajów wynika, że w eksporcie polegały one na przełamaniu dominacji krajów Afryki przez kraje azjatyckie - udział państw Afryki obniżył się z około 74\% w 1976 roku do około 39\% w 2013 roku, a udział krajów Azji wzrosł odpowiednio z 19 do 54\%. W imporcie natomiast utrzymywała się przewaga państw Afryki (ponad 83\% importu), wzrósł jednak udział krajów Azji (z 0,4 do 11\%), a zmniejszył się odsetek małych wyspiarskich krajów Oceanii (z 9,5 do $1,2 \%$ ) (obliczenia własne na podstawie FAO, 2016b).

W całym badanym okresie obroty charakteryzował wysoki stopien koncentracji. Na trzech najwiekszych eksporterów przypadało corocznie ponad $56 \%$ wywozu, na dziesięciu - ponad 92\% całkowitego eksportu LDC. Koncentracja w imporcie wykazywała natomiast tendencję malejącą - udział trzech czołowych importerów zmniejszył się z 61\% w 1976 roku do 52\% w 2013 roku (tab. 10). 
Tabela 10. Najwięksi eksporterzy i importerzy artykułów rybnych w grupie LDC w 2013 roku (udział w obrotach, \%)

\begin{tabular}{|lr|lr|}
\hline \multicolumn{2}{|c|}{ Najwięksi eksporterzy } & \multicolumn{2}{c|}{ Najwięksi importerzy } \\
\hline 1. Myanmar & 23,5 & 1. Angola & 28,5 \\
\hline 2. Bangladesz & 20,6 & 2. Kongo, Dem. Rep. & 14,2 \\
\hline 3. Mauretania & 12,7 & 3. Mozambik & 9,3 \\
\hline 4. Senegal & 10,4 & 4. Zambia & 5,4 \\
\hline 5. Jemen & 7,6 & 5. Haiti & 4,2 \\
\hline 6. Madagaskar & 4,7 & 6. Madagaskar & 4,1 \\
\hline 7. Uganda & 4,5 & 7. Benin & 3,9 \\
\hline 8. Tanzania & 3,0 & 8. Togo & 3,2 \\
\hline 9. Kiribati & 2,6 & 9. Jemen & 3,1 \\
\hline 10. Vanuatu & 2,4 & 10. Gwinea Rów. & 2,9 \\
\hline 11. Kambodża & 2,2 & 11. Bangladesz & 2,8 \\
\hline 12. Mozambik & 1,6 & 12. Myanmar & 2,2 \\
\hline 13. Wyspy Salomona & 1,3 & 13. Senegal & 1,9 \\
\hline 14. Tuvalu & 0,7 & 14. Mali & 1,3 \\
\hline 15. Angola & 0,6 & 15. Somalia & 1,1 \\
\hline Razem 1-15 & 98,4 & Razem 1-15 & 88,1 \\
\hline Pozostałe & 1,6 & Pozostałe & 11,9 \\
\hline LDC ogółem & 100,0 & LDC ogółem & 100,0 \\
\hline
\end{tabular}

Źródło: opracowanie własne na podstawie FAO (2016b).

Do największych eksporterów netto produktów rybnych należały w latach 1976-2013 Myanmar, Bangladesz, Mauretania, Senegal, Jemen, Wyspy Salomona i Madagaskar. Czołowymi importerami netto pozostawały natomiast Demokratyczna Republika Konga, Togo, Zambia, Benin, Haiti, Burkina Faso, Rwanda i Sudan. Diametralna zmiana salda obrotów dotyczyła natomiast Vanuatu, Tanzanii i Kiribati, które z największych importerów netto przekształciły się w eksporterów netto artykułów rybnych. Odwrotna tendencja wystapiła natomiast w handlu Mozambiku, Mali i Somalii (obliczenia własne na podstawie FAO, 2016b).

Zmiany w kierunkach sprzedaży i zakupów artykułów rybnych LDC polegały na wzroście udziału pozostałych krajów rozwijających się kosztem krajów rozwiniętych gospodarczo. Rola wymiany pomiędzy krajami LDC wyraźnie wzrosła po stronie ich eksportu, natomiast spadła w imporcie (tab. 11). 
Tabela 11. Kierunki eksportu i importu artykułów rybnych* LDC według grup krajów w latach 1995-2015 (\%)

\begin{tabular}{|l|r|r|r|r|}
\hline \multirow{2}{*}{ Kierunki eksportu/importu } & \multicolumn{2}{|c|}{ Eksport } & \multicolumn{2}{c|}{ Import } \\
\cline { 2 - 5 } & 1995 & 2015 & 1995 & 2015 \\
\hline LDC - LDC & 1,8 & 4,3 & 19,2 & 7,8 \\
\hline LDC - pozostałe rozwijające się & 19,5 & 42,8 & 47,2 & 68,6 \\
\hline LDC - rozwinięte & 77,8 & 51,5 & 31,8 & 23,4 \\
\hline LDC - transformacji & 0,5 & 1,4 & 0,0 & 1, \\
\hline
\end{tabular}

* Artykuły rybne z działu 03 klasyfikacji HS, stanowiące średnio około $90 \%$ eksportu i około $80 \%$ importu LDC. Źródło: opracowanie własne na podstawie UNCTAD (2017b).

Tabela 12 . Wskaźnik $\mathrm{RCA}_{i}^{*} \mathrm{w}$ artykułach rybnych LDC i wybranych grup krajów w latach 1976-2013 (\%)

\begin{tabular}{|c|c|c|c|}
\hline Lata & LDC & $\begin{array}{c}\text { Pozostałe kraje } \\
\text { rozwijające się }\end{array}$ & Kraje rozwinięte \\
\hline 1976 & 202,6 & 141,7 & 90,0 \\
\hline 1980 & 232,6 & 130,9 & 91,3 \\
\hline 1990 & 410,7 & 171,1 & 79,3 \\
\hline 2000 & 425,0 & 154,3 & 74,9 \\
\hline 2010 & 199,6 & 119,1 & 90,9 \\
\hline 2013 & 177,2 & 120,0 & 89,7 \\
\hline
\end{tabular}

${ }^{*} \mathrm{RCA}_{i}=$ udział sektora rybnego $\mathrm{w}$ całkowitym eksporcie danej grupy krajów odniesiony do udziału globalnego sektora rybnego w globalnym eksporcie.

Źródło: opracowanie własne na podstawie FAO (2016b); UNCTAD (2017b).

Dla określenia międzynarodowej konkurencyjności sektora rybnego LDC obliczono wskaźniki ujawnionej przewagi komparatywnej. Z kształtowania się wartości RCA ${ }_{i}$ wynika, że LDC wykazywały w całym analizowanym okresie przewagę komparatywną w produktach rybnych, znacznie silniejszą niż przewaga wykazywana przez grupę pozostałych krajów rozwijających się (tab. 12).

\section{Podsumowanie}

Na podstawie przeprowadzonych analiz można stwierdzić, że tendencje rozwoju gospodarki rybnej grupy krajów najsłabiej rozwiniętych kształtowały się korzystnie, o czym świadczą: 
- wysoka dynamika produkcji, konsumpcji i obrotów produktami rybnymi,

- korzystne relacje cen w handlu artykułami rybnymi i rosnące dodatnie saldo obrotów,

- międzynarodowa przewaga konkurencyjna sektora rybnego,

- wzrost udziału w globalnej produkcji, konsumpcji i eksporcie artykułów rybnych.

Główne kierunki zmian w sektorze rybnym LDC były zgodne $\mathrm{z}$ tendencjami występującymi w globalnej gospodarce rybnej i polegały na: wzroście udziału akwakultury i zmniejszeniu się udziału produkcji morskiej, zwiększeniu się roli krajów Azji w produkcji i eksporcie artykułów rybnych LDC oraz wzroście spożycia per capita przy rosnącym poziomie jego zróżnicowania między poszczególnymi krajami.

Pomimo wyraźnej tendencji wzrostowej, notowanej w ostatnich dwóch dekadach badanego okresu, rola LDC w światowej gospodarce rybnej była relatywnie mała. Do przeszkód w rozwoju sektorów rybnych w wielu z nich należały: niekorzystne warunki naturalne (brak dostępu do morza i/lub zbiorników wodnych na lądzie), niski poziom rozwoju gospodarczego oraz niedostatek zasobów pracy i kapitału.

\section{Literatura}

FAO (2016a). Food Balance 1961-2013 (FishstatJ). Pobrano z: www.fao.org/fishery/statistics/software/fishstatj /en.

FAO (2016b). Global Fisheries Commodities Production and Trade 1976-2013 (FishstatJ). Pobrano z: www. fao.org/fishery/statistics/software/fishstatj/en.

FAO (2016c). The State of World Fisheries and Aquaculture 2016. Contributing to Food Security and Nutrition for All. Rome: FAO.

FAO (2017a). FAO Fishery and Aquaculture Country Profiles. Pobrano z: http://www.fao. org/fishery/country profiles/search/en.

FAO (2017b). Global Production by Production Source 1950-2015 (FishstatJ). Pobrano z: www.fao.org/ fishery/statistics /software/fishstatj/en.

Golub, S., Varma, A. (2015). Fishing Exports and Economic Development of Least Developed Countries: Bangladesh, Cambodia, Comoros, Sierra Leone and Uganda. Swarthmore: Swarthmore College.

IMF (2015). Kiribati. IMF Country Report No. 15/207. 
Knap, R. (2012). Role of the Fisheries Sector in Social and Economic Development of Developing Countries. Actual Problems of Economics, 10 (2), 100-110.

MFED (2015). Fishing License Revenues in Kiribati. Bairiki: MFED.

OECD/FAO (2015). Fishing for Development. Rome: FAO.

Sumaila, U.R. (2017). Trade and Sustainable Fisheries. ADBI Working Paper, 676.

Thorpe, A. (2005). Mainstreaming Fisheries into National Development and Poverty Reduction Strategies: Current Situation and Opportunities. FAO Fisheries Circular, 997.

UNCTAD (2017a). UN Recognition of the Least Developed Countries. Pobrano z: http:// unctad.org/en/Pages/ALDC/Least\%20Developed\%20Countries/UN-recognition-ofLDCs.aspx eveloped-Countries.aspx.

UNCTAD (2017b). UNCTADstat Data Center. Pobrano z: http://unctadstat.unctad.org/wds/ TableViewer/table.

\title{
THE LEAST DEVELOPED COUNTRIES IN WORLD FISHERIES
}

\begin{abstract}
The aim of this paper is to define the trends of the development of the fisheries sector in the least developed countries (LDC) and their role in the world fisheries in the years 1970-2015. The research shows that the development trend of the LDC fishery sector has been favorable, as evidenced by the high dynamics of fish production, consumption and trade, the growing positive trade balance in fish products, and the international competitive advantage of the fishery sector. Despite the increase in global fisheries, the role of the LDC in this area of the world economy was relatively small. The main obstacles to the development of the fisheries sector in many LDCs were: unfavorable natural conditions, low levels of economic development and scarcity of labor and capital.
\end{abstract}

Keywords: least developed countries, development of fish sector, global fishing industry JEL codes: O13, O57, Q22 
